\title{
THE RESEARCH OF TECHNOLOGICAL APPROACH TO THE MODELING OF INFORMATION AND ANALYTIC PROVISION OF MANAGING AN ENTERPRISE
}

\author{
Tetiana Bochulia \\ Department of Accounting, Audit and Taxation \\ Kharkiv State University of Food Technology and Trade \\ 333 Klochkivska str., Kharkiv, Ukraine, 61051 \\ bochulya@i.ua \\ Andriy Yanchev \\ Faculty of Accounting and Finance \\ Kharkiv State University of Food Technology and Trade \\ 333 Klochkivska str., Kharkiv, Ukraine, 61051 \\ buhychet@hduht.edu.ua \\ Liana Yancheva \\ Kharkiv State University of Food Technology and Trade \\ 333 Klochkivska str., Kharkiv, Ukraine, 61051 \\ liana-nicol@i.ua
}

\begin{abstract}
The article is devoted to the solution of actual problems of innovative development of information and analytical provision of managing an enterprise according to the newest technology. A number of recommendations concerning technological upgrading foundation of modernization of information and analytic provision of managing an enterprise are elaborated. Technological approach to the modeling of information provision of business management is substantiated. Actualizing information and analytic provision of managing an enterprise has been carried out in developed flexible information system that is organized as internal network structure. Technological foundation of information and analytical process enterprise to modernize has been considered based on the modern tools of information and communication decisions. Information and analytical provision of managing have been developed through internal and external parallels of impact, which interconnection coordinates theory, methodology and organization of information processes with actualization of its model. The model of information and analytic provision of managing an enterprise according to the individual characteristics of corporate culture, and information environment and development strategy of business entity on the basis of characteristics of technological provision of information process is developed. Information complex has been suggested as developed system with technological process of forming initial data and modernizing processing, transmission and storage of information in accordance with distinctive characteristics of enterprise and general tendencies of its development.
\end{abstract}

Keywords: information technologies, development technologies, provision of business management, modeling.

\section{Introduction}

Modern information and technological transformation of socio-economic relations are causing scientific developments for provision of all levels of information requests with minimization of information asymmetry. Not only the factors of "physical world" (such as physical capital), but also technology, communications, institutional paradigm of economic theory, intelligence, knowledge, thinking are contributing development of enterprise information environment. Information and analytic provision of managing an enterprise is formed and developed under the impact of environment, in which business entity carries out activities according to the processes of processing, transmission and storage of information, implementation of technological and communication innovations that are the result of technological development of global economy.

With the development of information economy the proprietors and managers in a new way evaluate the need for modernization of management on technological and communication basis that is substantiated by the computerization of information system as an integrated organization of data, technologies, communications, algorithms, methods, principles, etc. Modification of information 
processes gets particular relevance, for what their models are formed on the basis of personalized characteristics of enterprise activity.

\section{Literature review and problem statement}

The formation model of information and analytical provision of managing an enterprise envisages announcement of transition to new methodological level of information processes on the basis of implementation of technologies with modification of enterprise information environment for increasing the efficiency of making decision. European intentions of Ukraine concerning the integration into global economic environment are considered [1]. The new approaches to organization of management system to obtain sustainable competitive advantage are substantiated [2]. Organizational aspects of forming management policy and regulation of information processes are suggested [3]. The development of information and economic environment are substantiated by developing new and qualitatively best technology [4]. The model of corporate information system is suggested that contributes to automation of core directions of business activity [5]. The actualizing ways of forming information in the accounting system are described [6]. Organizing communication environment in the accounting system is considered [7]. The impact of globalization processes on development of enterprise information environment is described [8]. The dependence of information and analytical provision of managing on the development and implementation of innovative technologies is substantiated [9]. The emergence of synergies in enterprise information system is described [10]. But systematization of approaches to development of information and analytical provision of managing an enterprise in conditions of communicative rationality of global information space, redesigning of economic relations is topical. It is necessary to generalize the empirical experience of processing, transmission and storage of information, modification of theoretical, organizational and methodological foundations of information processes, organization of enterprise information environment taking into account the need for customization (formation of data at new quality for satisfaction of user's inquiries). The task for modern scientific research is creating a radically new subsystem of enterprise management that should be developed through implementation of technologies and approximation of theoretical and methodological foundations of modern management concepts.

\section{The aim and the tasks of the study}

The aim of research is formation of the model of information and analytical provision of managing an enterprise for forming information that performs a specific group of management tasks with increasing the transparency of factors of enterprise activity evaluation for interested users and increasing the objective possibility of partnerships with external economic environment.

Following tasks have been resolved to achieve this goal:

- information and analytical process in developed and flexible information system that is organized by internal network structure to actualize;

- technological foundation of information and enterprise analytical process to modernize the considered;

- information and analytical provision of managing to develop through internal and external parallels of impact, which interconnection coordinates theory, methodology and organization of information processes with actualization of its model.

\section{Materials and methods of the study}

The totality of scientific methods for cognition of processes and phenomena that are basic for development information and analytical provision of managing an enterprise has become theoretical and methodological basis of research. In research were used: nosological method - for concretization of main emphasis at forming model of information and analytical provision of managing an enterprise; the methods of theoretical generalization and comparisons - to determine the prospects and trends technologizing of information and analytical provision of managing; method of analogy - to construct the model of information and analytical provision of managing. 
The economy needs changes, transformations and innovations, provided by generation and dissemination of new knowledge that directly depends on planetary information sphere as a result of adapting social and economic institutions to becoming of information paradigm of the modern world development. The need for change of inertial industrial development to the one, which would correspond to the requirements of modern stage of scientific and technological revolution, has become logical [1]. The science as the highest level of developing management, rational and irrational thinking, creativity of intellectual decisions, development of new information tasks are the basis of such changes.

Innovations, needed by the modern economy are emerging from chaos. Practical recommendations on intensification of critical thinking and promoting integration of sustainable development at enterprise model with expansion of core competencies are proposed in scientific research [2]. The provision of enterprise development is implemented through the complex system of organizational, informational, technological, methodological and philosophical redesigning of information process in accordance with achievement of multipurpose aspect of information. The processes that reflecting the impact of formal and informal institutions, rules of which regulate sustainable economic development, provision of business interests and increasing its value through functionalities of innovative products are integrated and interrelated by the use of computer technologies in information process.

The forming model of information and analytical provision of managing has been developed at organizational and methodological level that has revealed new possibilities for modification of enterprise information processes. The modeling of information and analytical provision of managing were carried out on methodology stage, when methods, objects, elements, principles of organizing enterprise information environment that is a base for making decision are elected according to the activity purpose.

\section{The results of studies}

Information and communication technologies have become a tool that allows organize most effectively the movement of information with ignoring boundaries and time. Technical provision of information system is a complex of hardware and communication tools that are necessary for forming, processing, transmission, storage of economic information. The software includes the totality of programs, adapted to solve specific functional tasks that correspond to technical specifications of hardware and communication system. Software is a basis for organization, management and control of information. Linguistic provision is organized in order to optimize work of the person and machine and for elimination of contradictions at interpretation of entered data with their subsequent processing and generation of cumulative information result. The quality servicing of information and communication technologies depends on three groups of factors:

1) that are not directly depends on enterprise (political, economic, scientific and technological factors);

2) which are directly depends on enterprise activity and staff qualifications;

3) subjective characteristics and the uniqueness user [3].

The uniqueness of technologies at their modification provide the individual approaches to automation of information and business activity that contributes to the development of various software decisions that is more developed in comparison with boxed software. The technologies contributed to intensify «creative destruction» of economy under which business entities should carry out activities [4]. The destruction in this sense has creative character that consists in actualization of rules of formal and informal institutions and achievement of balance at their impact on functioning of economic, social and ecological systems. Modern technological decisions are implemented as creative, in which experience not only programming but also interdisciplinary knowledge from various sciences are generalized that are qualitatively developing information activities of enterprise, market, economy and the world.

The approaches to organizing and servicing business and information processes are implemented at enterprise software as a unity of software and technological decisions and hardware and communication equipment. Universal approach to computer decisions is replaced by individual 
approach that is more effective for modern enterprises activity. Big enterprises are organizing own corporate information system that automates core directions of business activity [5]. According to analogy with corporate culture, the uniqueness of software complex is justified considering complex information, financial and economic relations that need consideration of additional nuances of organizing and serving enterprise information system.

Information and analytical provision of managing an enterprise is organized by its inclusion to integrated information and communications infrastructure, which operates through the contours of internal and external appointment. The contours of internal appointment are adapted to servicing of information and communication activity inside the enterprise and implemented by the complex of technical and technological means, organizational systems and regulatory base that serve internal management processes and information flows. External contours serve information infrastructure of economic systems with creating basis for flexible information and communication activity and contributing to servicing of centers and channels of processing, transmission and storage of the data. Internal infrastructure interacts with external infrastructure through the open channels of communication within the limits of access that allows continuous monitoring of requests of different users.

Automatization management of information processes is not strategic goal of enterprise activity but instrument (base) for its achievement. The functionality of technologies for conversion of input data in relevant information in order to meet requests of management process is implemented in technological provision of information system. "Input" and "output" of data are necessary to coordinate with organizing automated system to provide integration between information subcenters and to overcome isolation of information processes.

Technological organization of information and analytical provision of managing an enterprise has powerful instruments and technologies for constructing full-featured integrated platform, which is necessary to support all business applications that are adapted to exploitation, servicing and modification. This is not only work at certain operating system, but also environment of technologies for organizing technological, methodological and professional provision. It is important to organize the processing of information in accordance with determined algorithm and make it such, which corresponds to organizational structure of business entity. Consideration of enterprise information policy that reflects nuances of forming information to satisfy the multifaceted different users' queries is compulsory.

Technological decisions contribute to efficiency of information and analytical process with new level of servicing corporate database, which accumulates information that is needed for management decisions (Fig. 1). It is actualization of information process in developed, flexible system that is organized as internal network structure, which operatively reacts to changes of internal and external environment with increasing rate of reaction for forming quality management information.

Information flow needs to be synchronized at enterprise development considering the communication "subject - subject" in the context of symmetry and the content of information, frequency of communications, etc [6]. In this context it is expedient to use phrase "parallel connections" that more correctly reflects opinion about customizing information processes, because there happens not only synchronization, but also parallel execution of tasks with varying complexity and focus is implemented. It's organizing bilateral information relations that contribute to detailed elaboration of information management with identifying interdependencies between indicators and impact factors of their receiving.

Information communications are the process of information exchange between elements of management system of different hierarchical levels based on the diversity of connections between such elements to improve coherence of their functioning and interaction (internal communications) and between systems of external environment (external communications) [7]. The communication in information system has economic orientation in spite of dominant social subtext.

Information and communication possibilities of information and analytical provision of managing an enterprise are developing in accordance with modernizing innovative technologies considering the mass character of data and complexity of management tasks. 


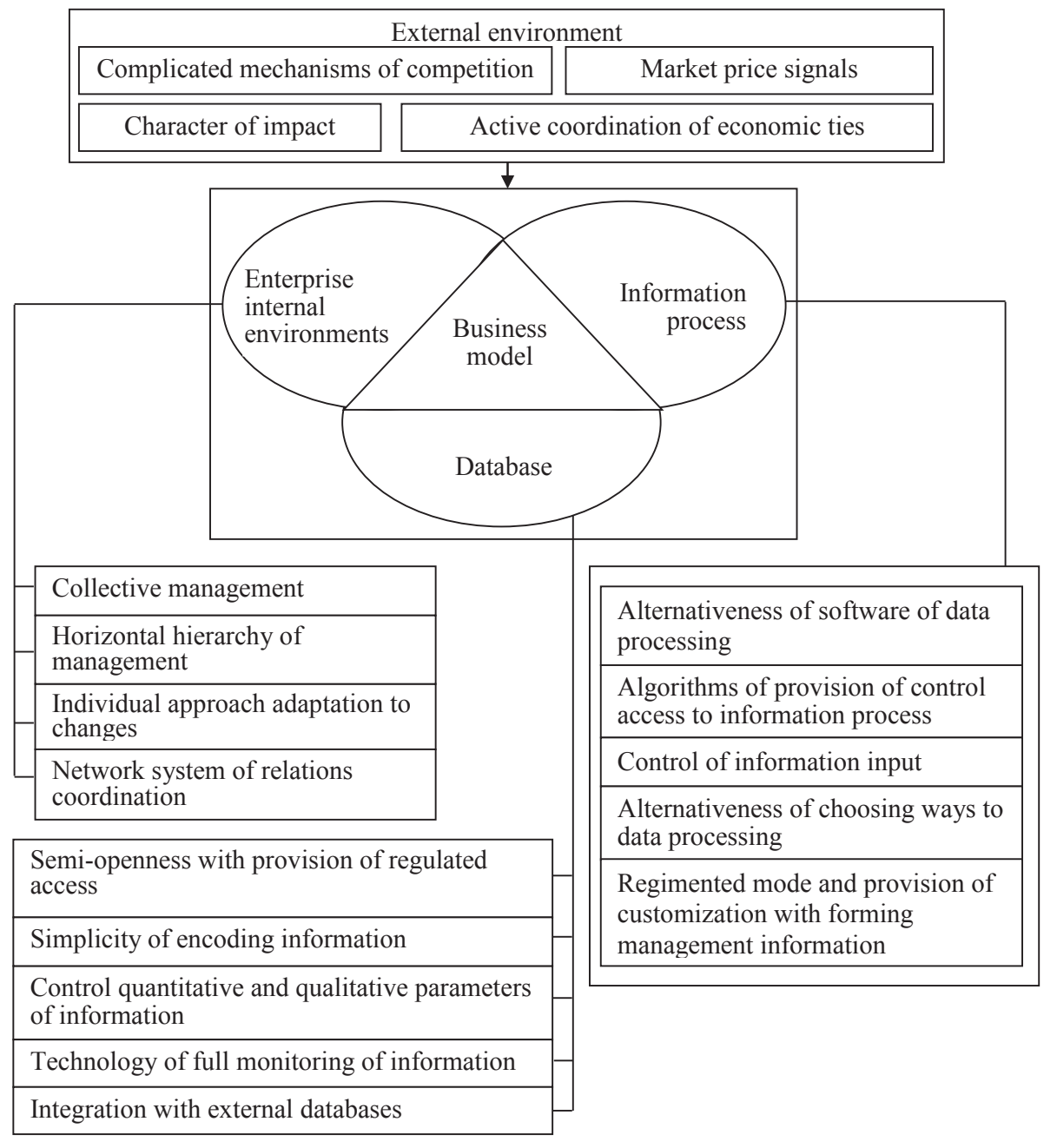

Fig. 1. Technological foundation of modernizing information and analytical provision of managing an enterprise

Servicing of information and analytical provision of managing with implementation of functionalities information and communication technologies is achieved by forming of structure of information relations in integrated enterprise information system, which logic of development strategy of business entity is incorporated with timely identification of changes, setting goals and developing models of appropriate reaction. The results of enterprise activity, which information is processed and generalized by the information system that is coordinated by management decisions, that depends on subsystems of control and analysis.

The new opinion of organizing information and analytical provision of managing is used by modification processing, transmission and storage of information by forming of information complex that functionality of management subsystems, technological support and communications are integrated in. Their implementation actualizes organizing of information system and provision of effective connections between management subsystems with optimization of enterprise information environment. Information complex is designed for measuring, forming, processing, transmission and storage of information about: current indexes of business processes; maximum allowable parameters values in accordance with business goals and strategies; planned indicators according to decisions as unity of opportunities, potential, risks and development strategy; tax payments of reporting period with possibility of analysis of their dynamics; indicators of enterprise activity; data for objective making decision. 
Technological process of forming output data is actualized and information process is developed in information complex - database, processing, transmission and storage of data, relevant information in accordance with distinctive characteristics of enterprise, general trends of its development and external context. Information base is not limited to the relevant data in information complex and includes data that are obtained from alternative sources and contribute to increasing professional competence of specialists. Organization of this part of information and analytical provision of managing is coordinated by professional regulators with creating environment for consultation and forming relevant data that are necessary for continuous optimization of enterprise database.

The proposal of organizing information complex is direction of scientific development of information and analytical provision of managing an enterprise going beyond the traditional approach to forming system and considering the functionality of modern information and communication technologies. The processes of upgrading technical, technological and information provision are synchronized in information complex that minimizes disintegration of economic information and reducing the risks in management decisions.

Forming of information is based on software systems and provides designing of database with filters for regulation of information by levels of making decision that is necessary for qualitative information exchange. Information processes are included in the shell of database management systems and their organization is aimed at rational distribution of information resources and to prevent accumulation of unnecessary data [8]. Technological processes in information systems are based on developed databases and search services that provide forming information resources and regulation of time factor with the balance "operativeness - price - quality".

Technological organizing of information and analytical provision of managing includes search, filtering, synthetic and analytical processing, operative displacement and implementation, systematization, publication and archiving of information in all forms that should be regulated by relevant internal and external standards of legal, organizational and methodological character.

Extremely complicated conditions of economic activity, which are caused by impact of technological and intellectual transformation of society and the economy, require the development and implementation of new management decisions, which basis is information and analytical provision of managing an enterprise. Its forming and using allow improving the information content of decisions and will contribute to their effectiveness.

The organizing of information and analytical provision of managing an enterprise should be modeled according to the different levels of its regulation that cumulatively contributes to result, expressed by universal information resource for database, which is accessible and relevant to all management subsystems. Now not only the developed model of information and analytical provision of managing an enterprise is demanded, but also such model, in which information process is actualized with expansion of competencies of enterprise information system.

Information and analytical provision of managing is a core source of management information. It is advisable to consider not only information, for which economic and legal interpretation is inherent, and also take into account the facts of business activity that are describing strategy and business tasks with forming basis for adequate assessment of financial and business condition of enterprise by indexes of reporting. Information and analytical provision of managing should be developed through internal and external parallels of impact, which interconnection coordinates theory, methodology and organizing of information processes at actualization of its model at three interpretations according to the level of openness and structuring of information concerning different sides of enterprise activity (Fig. 2) [9].

The model of information and analytical provision of managing an enterprise is formed according to individual characteristics of corporate culture, information environment and strategy of business entity development on the basis of characteristics of the external environment. The model of information and analytical provision of managing acquires organizational and methodological features, which contribute to forming information that performs some group of management tasks. 


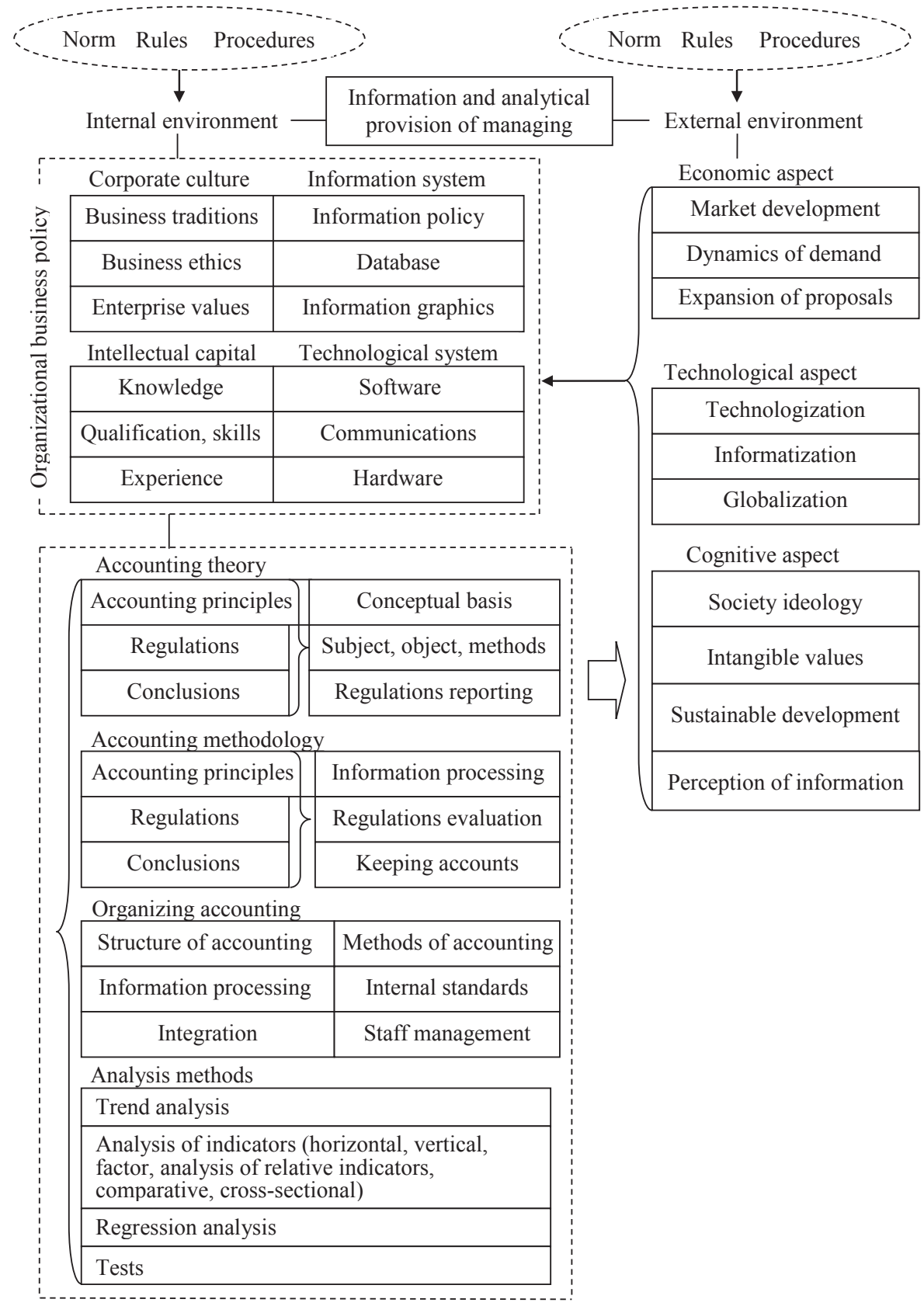

Fig. 2. Model of information and analytical provision of managing an enterprise

Enterprise gets opportunity to establish the effective information basis of management during the forming model of information and analytical provision of managing that fully corresponds to own strategy with objective assessment of possible risks and their prevention and skillful implementation of potential and affects not only revitalization of activity enterprise, but also increases objective possibility of partnerships with external economic environment. The pattern of integration and presentation of data at predetermined form is incorporated in the model of information and analytical provision of managing that causes conditional digits, which characterize the business system with its assets, liabilities, real capital, risk, prospects etc.

The improvement of efficiency of information at information and analytical provision of managing is carried out at the expense of "...synergetic effect as a result of integrating theoretical, methodological and organizational components of forming and provision of all spectrum of information into single system and their complex interactions" [10]. 
Information and analytical provision of managing for the management environment of enterprise should be conscious choice, business position, which business entity selects the reliable information lever for revitalization of activity that ensures the business dynamic to certain extent. Information and analytical provision of managing an enterprise has high potential as environment of relevant economic information for decision making system.

\section{Discussion of the results}

Management information is characterized by complex the set of multilevel communications with multifaceted internal organization; considerable massiveness and volume are inherent for it that are directly related to the object of management, which development is carried out in synchronization with general transformations at external economic environment. Management process in this context is based on provision of accurate results of information process and timeliness meets the needs of users in making management decisions.

The proposals for informatization of information and analytical provision of managing an enterprise are designed for: continuity of processing information regardless of its volume in real time; coverage of the entire cycle of processing indicators of enterprise activity; simplification of processing of large amount of information taking into account the different criteria with provision of various information requests; operative synthesis of information during its circulation at the different levels of management; operative transformation of indicators at convenient form for users.

Technology of information and analytical provision of managing has not only processes, and also elements, which characteristics determine the order of information processing. The development of information and analytical provision of managing an enterprise contributed to organic combination of information with characterizing of past, present and future that corresponds to the stages of information process according to the recent results of the implementation of software products and intelligent decisions in processing, transmission and storage of information.

Information and analytical provision of managing is individual information model of enterprise, which is formed as a set of formal and informal rules according to business model, draft decisions and scenario of development that shall be redesigning in accordance with trends of information economy. Forming of conditions for the development requires actualization of information process with synchronizing of changes in enterprise management subsystems. Creative potential as a result of expansion of professional competencies should be implemented at development of information and analytical provision of managing for correct choice of methods, technologies and procedures for its redesign.

\section{Conclusions}

1. Forming complex automation system of information and analytical provision of managing an enterprise was carried out through integration of information system components, information infrastructure elements, communications and technologies, normative legal, methodical and professional provision that regulates procedure of forming information base to meet the modern user requests in accordance with certain level of access for each of them. Information boundaries of enterprise management have been expanded on the basis of information and communication technologies and integration of formal and informal regulators of organizing information environment that allows increase the total cumulative effect of using information.

2. Organizing information and analytical provision of managing depends on conditions and factors of institutional environment development, technological potential and dynamics of professional provision that is a basis for making managerial decisions, development of business and economy as a whole. Forming model of information and analytical provision of managing as information microenvironment with generation of managerial data and communication links of two-dimensional character (inside and outside), with data integration at clearly defined information boundaries that depend on regulation of formal institutions has been substantiated.

3. Individual model of information links is inherent to each enterprise that involves organizing information and analytical provision of managing, which is formed by some combination of information that provides distinctive features and attributes that reflect business model of enter- 
prise, complex of its management patterns and development scenarios. The model of information and analytical provision of managing an enterprise is proposed for formation according to the individual characteristics of business entity on the basis of processes, decisions, competencies and motivations, which are organized and provided by information.

\section{References}

[1] Palahnyuk, Yu. V. (2010). Ekonomichni aspekty intehratsiyi Ukrayiny do YeS (u ramkakh diyi Uhody pro partnerstvo i spivrobitnytstvo). Naukovi pratsi Chornomors'koho derzhavnoho universytetu imeni Petra Mohyly kompleksu «Kyyevo-Mohylyans'ka akademiya», 147 (135), 22-27.

[2] Laszlo, C., Zhexembayeva, N. (2011). Embedded Sustainability: The Next Big Competitive Advantage. Stanford Business Books: Stanford, CA, 288.

[3] Kovshova, I. O. (2012). Formuvannya imidzhevoyi polityky korporatyvnykh pidpryyemstv informatsiyno-komunikatsiynoyi sfery. Available at: http://ena.lp.edu.ua:8080/bitstream/ntb/16026/1/13-Kovshova-85-90.pdf

[4] Danylyuk, O. Yozef Shumpeter: «Protses tvorchoho ruynuvannya ye samoyu sutnistyu kapitalizmu». Available at: http://www.management.com.ua/vision/vis021.html

[5] Savchenko, A. (2011). KIS kompanii kak gibridnoe oblako. Intelligent Enterprise, 7. Available at: https://www.iemag.ru/analitics/detail.php?ID=23791

[6] Lahovs'ka, O. A. (2011). Morfolohichnyy pidkhid do formalizatsiyi komuni-katsiynykh zvyazkiv systemy bukhhalters'koho obliku. Problemy teoriyi ta metodolohiyi bukhhalters'koho obliku, kontrolyu i analizu, 3(2 (21)), 169-178.

[7] Lahovs'ka, O. A. (2011). Orhanizatsiyni komunikatsiyi v systemi upravlinnya: oblikovyy kontekst. Mizhnarodnyy zbirnyk naukovykh prats', 3 (21), 222-232.

[8] Bochulia, T. V. (2013). Teoretychni zasady oblikovo-informatsiynoho zabezpechennya biznesu v umovakh hlobal'nykh zmin. «Modernizatsiya ta suspil'nyy rozvytok ekonomiky krayiny» Simferopol: NO «Economics», 112-114.

[9] Bochulia, T. V. (2015). Innovatyvnyy rozvytok oblikovo-analitychnoho zabezpechennya upravlinnya pidpryyemstvom. Kharkiv: VD «INZhEK», 404.

[10] Kuznetsova, S. A. (2012). Synerhiya informatsiyi v biznesi. Dnipropetrovs'k: Dnipropetrovs'kiy universitet imeni Al'freda Nobelya, 120. 